\title{
Transforming Alyosha into Superman: Invented Traditions and Street Art Subversion in Post-Communist Bulgaria
}

\author{
Bozhin Traykov, \\ University of Alberta
}

The Monument of the Soviet Army (MSA) situated at the Borissov Garden in the Bulgarian capital Sofia, is one of the largest architectural and sculptural monument complexes in the country. It was opened in commemoration of the $10^{\text {th }}$ anniversary of September $9^{\text {th }} 1944$ - the date when the Fatherland Front took power and the Red Army entered Bulgaria. On December $4^{\text {th }} 1949$ the Council of Ministers of the Bulgarian Communist Party (BCP) decided to build a monument of the Soviet Army. The monument was designed by a team led by one of the founders of Bulgarian Socialist realism Ivan Funev, and included prominent artists such as Lubomir Dalchev, Mara Georgieva, and Vaska Emanouilova. The official opening was on September 7th, 1954, in the presence of Soviet Marshal Sergei Biryuzov.

A wide alley bar, 80 meters long and 28 meters wide leads to the monument. In front stands the inscription "To the Soviet Army liberator by the grateful Bulgarian people." At the front of the alley two groups of sculptures depict Bulgarian people welcoming the Soviet Army. The monument itself is a high truncated pyramid on which stands an eight foot sculpture of a Soviet soldier waving a Shpagin machine gun. Bulgarian male worker and a peasant mother with a child, walk on each side of the soldier, both of them substantially smaller in size. The bottom of the monument depicts the establishment, consolidation and the victory of the Soviet Army. The East side of the monument entitled "October 1917", in reference to the Russian revolution, depicts the "volunteers that formed the Soviet Army with revolutionary enthusiasm." The South side of the complex entitled "Everything for the front, everything for victory," shows all the Soviet people in the rear pooling all their efforts to help their army. The sculptural component on the west side of the monument, entitled "The Patriotic War" "is meant to show the battle zeal and indomitable power of the Soviet Army." On June $17^{\text {th }}, 2011$ the West side of the MSA underwent a peculiar transformation.

People were staring with dismay at the commanding officer of the Red Army, still menacingly holding a pistol and urging his soldiers to attack, but now wearing the clothes and insignia of Superman. Behind him a soldier had turned into Ronald McDonald, waving a flag that instead of the hammer and sickle of the Soviet Union had the stripes and stars of the U.S.A. The rest of the platoon consisted of Captain America holding a machine gun; Wonder Woman behind him; the Joker holding a weapon and advancing upfront; Robin in charge of a cannon; and Wolverine throwing a grenade. Santa Claus stood shoulder to shoulder with Superman, with a binoculars in one hand and a Shpagin machine gun in the other, making the grotesque composition complete. Captioned underneath were the words: "In Pace with the Times." Overnight, graffiti artists replaced the advancing soldiers of the Red Army with American superheroes and icons of consumer culture. The artwork remained for three days and then disappeared in the same manner it had appeared-as an overnight subversive act. 
The graffiti reignited an emotional debate about the future of the monument. The destiny of MS $A$ has been a bone of contention since the fall of the Berlin wall. In 1992 Presidents Zhelev and Yeltsin signed a treaty on friendly relations and cooperation between the Russian Federation and the Republic of Bulgaria, which required to keep and maintain the monuments related to their history and culture. On March 18 $8^{\text {th }}$, 1993 Sofia Municipal Council decided to dismantle the Monument of the Soviet Army, this decision however never came into effect. At the end of the '90s, young people inhabited the space where they regularly organized beer fests and concerts. In October 2010 a group of citizens resumed the debate around the monument, creating a nomination committee to dismantle the monument and implement the March 1993 decision. They advocated that sculptures be moved to the newly built Museum of Totalitarian Art in Sofia. Until, on June 17 ${ }^{\text {th }}$, 2011, on the eve of the festival Sofia Design Week, graffiti artists transformed the West bas-relief memorial which created a furor in the city, and generated many contradictory statements and actions by the media and politicians. On June $21^{\text {st }}, 2011$ at dawn the monument was cleaned by the Forum "Bulgaria - Russia."

Bulgarian society was polarized over the intervention on the monument. The Russian embassy sent a protest note and demanded punishment for the 'vandals', while numerous Facebook member groups formed in support of the artists, who in some instances were even depicted as brave heroes daring to stand against the 'occupiers'. On the other side of the barricade were those for whom the monument elicited nostalgic feelings of the social safety of the old regime that the 'liberators' brought. The event even gained international significance with the likes of CNN and the Toronto Star admiring the "Banksy" of Bulgaria — a country, rarely mentioned in Western media and usually in the discourse of Balkan corruption and crime.

To map reactions to the transformation of the Monument of the Soviet Army, I conducted an informal content analysis of online media sources, including online forums and blogs. Examples of sources that I examined include the online media: dnevnik. bg and its forum section; mediapool and its forum section; the online newspapers 24hours and standart, Bulgarian National Television (BNT); declarations of political parties and cultural and intellectual organizations; blog of journalist Ivo Indzhev, the online forum of young mothers, bg-mamma, etc. Based on this review, reactions to the transformation of the Monument of the Soviet Army in the media appeared to fall into three main categories that bear on the historical conditions of collective and political memory.

The first category is comprised of those who engaged in an anti-communist narrative. Those who fall in this category expressed approval of the monument's transformation because they associate the monument with the totalitarian past. The presence of the monument functions to signify the horrors of Communism and the shame of foreign domination. Such discourses are rarely critical of the present course of neoliberal capitalism and view the nomenklatura (the Party elite) as solely responsible for the current socio-economic plight of Bulgarians. Journalist Ivo Indzhev and historian Plamen Tzvetkov are the main representatives of the anti-communist discourse. The centre right political spectra in Bulgaria, that played an instrumental role during the neoliberal reforms, are another such representative. Evoking the memory of the totalitarian past, especially in the first decade after the fall of Todor Zhivkov's regime, has become a potent political instrument, aiming to delegitimize today's socialists by denouncing them as former Communists in their claims to power. 
Recently such narratives have been extended to the silenced past of the Bulgarian anti-communist resistance, which aims to revitalize the narrative of the totalitarian past, but also contests the traditional notion of Bulgaria as the most loyal Soviet satellite. Many online users in the media forums I examined espoused this narrative.

The second category draws on a nostalgia narrative that is closely linked to the myth of "double liberation" which I will discuss below. It views the former regime as a time of social stability and protection under the wing of the Soviet Union. An example of such discourse is the declaration signed by members of organizations directly associated with the former nomenklatura that have fallen out of favour of the neoliberal state but still possess significant social capital. Contrary to the anticommunist narrative that questions the existence of fascism in Bulgaria, the nostalgic narrative views the monument as signifying Bulgaria's, and Europe's, liberation from fascism. Nostalgia narratives appear to appeal mostly to today's 'losers from the transition' to capitalism-primarily the elderly who long for the social safety of the old times. But, if we consider other indicators, such as the popularity of Bulgarian movies from the socialist period, the nostalgia narrative also appears to have an even broader resonance.

The third category can be called the commodification narrative. This is the category of responses that try to find meaning of the monument's function in accordance with the demands of neoliberal tourism. After the process of de-industrialization of the Bulgarian economy the main source of revenue became tourism, characterized by a tendency to turn public art into a commodity. Many opinions expressed in the online forums I reviewed pointed to the attractiveness of the transformed monument for tourist consumption. The views in this instance are consistent with a broader trend. Despite some exceptions the reading of the monument's transformation was quite limited and fell under the polarized categories of for (meaning approval of the act to disapprove of the past; or as an easily digestible tourist product, oftentimes both views overlapping) or against (meaning treating the act as an attack on the past, while failing to read it in the context of the present). That is, all of the major narratives associated with the monument pertain to the question of the formation of dominant discourses about history and identity where the monument's presence functions as a symbol that ignites such discourses.

Drawing on Eric Hobsbawm's theory of the invention of tradition I will demonstrate how the location of the Monument of the Soviet Army constitutes a symbolic space where ideologies become materialized in rituals and commemorations to affirm perceptions about the past and present. Further I will show how those ideological practices and narratives are negotiated in the realm of culture. As Hobsbawm points out the invention of traditions is a symbolic act that seeks to legitimize power by demonstrating continuity with the past. He argues, however, that imagery, symbolism and rituals are not only used to affirm the building of the nation-state, but also to counterweight the rise of popular democracy and the political involvement of the working classes. France of the Third Republic (1870-1940) and Germany in the time of Bismarck (1871-1890) are two cases in which traditions were invented both to commemorate the nation-state and to mitigate the radical movements inside those states. After unification Germany defined itself as a nation by what it 
was against - France as an outside enemy. The Franco-Prussian war became part of an invented tradition that attempted to unify all those various social groups under the banner of the nation.

In a similar way to Germany, we can trace how identifying the national enemy became part of the invented traditions that justified the creation of the Bulgarian nation-state, with a number of important implications. The Ottoman Empire became a symbol of the national enemy. An indelible part of the formation of nationalism was the perception of Bulgarian people's experience under the Ottomans, formed during the Revival period, as being enslaved by a civilizationally inferior power (Rumen Daskalov, The Making of a Nation in the Balkans). In that sense such an assessment of the Ottoman Empire is in accordance with the narrative of modernity, where in the era of the Cold War for Bulgarians the Soviet Union replaced Europe as a signifier of modernity (Kosseva, Zhelyazkova, and Hajdinjak). The notion of Ottoman slavery is deeply engraved in national mythology. This ideological explanation of historical periods is enhanced by the representation of the Revival period (1762-1878) not only in art and culture, but also in scholarly work as a symbolic period of awakening from darkness. The $19^{\text {th }}$ century Revival period functions as a founding myth about the birth of the nation, or re-birth from the dark ages of Ottoman rule(Rumen Daskalov, The Making of a Nation in the Balkans).

The governance of the Party-State during the Bulgarian People's Republic (1944-1989) was legitimized by the second liberation of the Soviet Union, this time from the Bulgarian government itself, characterized as fascist monarch (Rumen Daskalov, Debating the Past). The result is a powerful myth of 'double liberation' - the notion of the Russians saving Bulgaria from slavery in the $19^{\text {th }}$ century and then, a second time, liberating Bulgarian people from themselves. This is how the PartyState's official historiographers rewrote events of the past. The Ottoman period as 'slavery' formed as a myth early on before the formation of the Third Bulgarian Kingdom and continues to live in political and media rhetoric. Not surprisingly, it is still the core of ethno-nationalism and it lent itself to a strong nationalist sentiment during the debate around the transformation of the Monument of the Soviet Army.

Although more nuanced assessments of this period have been published in Bulgarian historiography, the slavery narrative continues to live in public discourse and is taken up regularly by the media and politics. ${ }^{1}$ This attempt to present Bulgarians' experience under the Ottoman rule as slavery affirms the dichotomy enslaver-liberator, where Russia is assigned the role of a liberator. Bulgaria gained its independence as a result of the Russo-Turkish war of 1877-1878. Gratitude for the liberator became an indelible component of the nation-building process that required invented traditions. This gratitude continues to be present in the commemoration of the peace treaty of San

\footnotetext{
1 See for example the reactions to Martina Baleva and Ulf Brunnbauer 's project "Battak as a Bulgarian Place of Remembrance" that examined the role of fine arts in the creation of national myths. The authors were accused by media and political figures, including President Purvanov, of trying to manipulate Bulgarian history and deny the existence of massacres during the unsuccessful uprising against the Ottoman Empire of April, 1876. One television station, Skat. went as far as to announce a reward for those who provide the address and picture of "the national traitor"-Baeva.For discussion of Bulgarian historiography before and after 1944 see:(Todorova; Rumen Daskalov, The Making of a Nation in the Balkans; Roumen Daskalov)
} 
Stefano on March $3^{\text {rd }} 1878$. The day of the treaty is now celebrated as the official national day. It not only signifies Russia's status as liberator of Bulgaria, but is also a constant reminder of the dream of national unification that never materialized (Kiossev).

MSA exists as part of a space that characterizes the modernization projects undertaken by the Bulgarian state in different historical periods. This is where the crossroads of the projects of modernity intersect: the institutions and ideological symbols of power and culture are all in proximity to each other - Sofia University built in the late $19^{\text {th }}$ (the oldest in the Balkans') faces the Borissov Garden and thus MSA; further, the parliament that dates back to 1879 neighbours the Alexander Nevski Cathedral completed in the 1920s (the biggest in the Balkans'). If one walks down the square, one will come across the building of the Bulgarian Academy of Science, built in 1892. Further down Tzar Liberator Boulevard, after passing the former king's palace, now the National Art Gallery, one will come across the Stalinist baroque style of the Ministry and Presidency building built in 1950s.

Numerous monuments all over the country commemorate both the Russian and Soviet liberators but two capture the essence of the historical myths that play a role in the invention of traditions in Bulgaria: The monument of Russian Tsar Alexander II-Liberator-the location of which symbolizes Bulgaria's status in Russian-Bulgarian power relations - facing the parliament; another is the MSA built centrally in the park opposite Sofia University, near the parliament; to emphasize the symbolic significance of both location and purpose I will point out that Bulgaria's biggest and most significant religious temple — the Eastern Orthodox Alexander Nevski Cathedral— named after a Russian Prince and designed by a Russian architect, completes this symbolic triangle. The triangle forms a public space that both affirms and challenges symbolic power relations and liberation/slavery narratives. The space between Alexander Nevski Cathedral and the statue of Tsar Alexander II is where the past meets the present. That was the main space of commemoration and celebration of national holidays during the period 1944-1947 when the Fatherland Front organized parades and demonstrations to legitimize the power of the Communists by linking the liberation of 1878 with the events of 1944. Thus, veterans of the war of 1878 participated hand in hand with the partisans of the anti-fascist struggle (Sygkelos).

Thus, the space between the Borissov Garden, where MSA is located, and Alexander Nevski square functions as the space that engages in the rituals of the invented traditions of the state. If in the period of the Party-State it became the arena where the rituals associated with the regime were practiced, after 1989 it transformed into a space where this very same regime was contested. In the last two decades Nevski Square has become a manoeuvring ground where the character of the transition gets negotiated. In recent collective memory Nevski Square signifies spatially and temporally the beginning of the democratic processes where the first meetings and protests against the old regime were held, a place of hope and optimism for a better future. The Monument of the Soviet Army, on the other hand, one of the symbols of Communist invented tradition, was recently ironically updated to the new realities. 
The public art of power relies on ritual to sustain its reverence but the mechanical reproducibility of art (Benjamin) opens it for political intervention, i.e. it reveals the dialectical aspect of technological development-it affirms power interests but it can become a tool for what Foucault would term the practice of liberty (Foucault). The technological development creates the potential for democratic, revolutionary art. Technologies of reproduction make the public art of state power easily exposed to the subversive potential of political art. State architectural planning is what Michel de Certeau calls the strategies of power (Certeau). The strategies of the powers that be have a spatial dimension: the aim is to transform space through the mechanisms of power-planning of architects, reconfiguring of cities so they do not pose a threat (potential spaces for revolutionary barricades; public spaces for protests). De Certeau, however, discusses a dimension that confronts the spatial planning of the strategic power: The temporal dimension of the tactics of those who refuse the monoglossia of the strategies of economic and political power (Certeau). Graffiti art could be such a temporal tactic that is always at war with the strategic spatial dimension, creating temporary autonomous spaces in places appropriated by capital or sterilized by the city government. Not surprisingly, graffiti art is demonized as crime by the official language of state power.

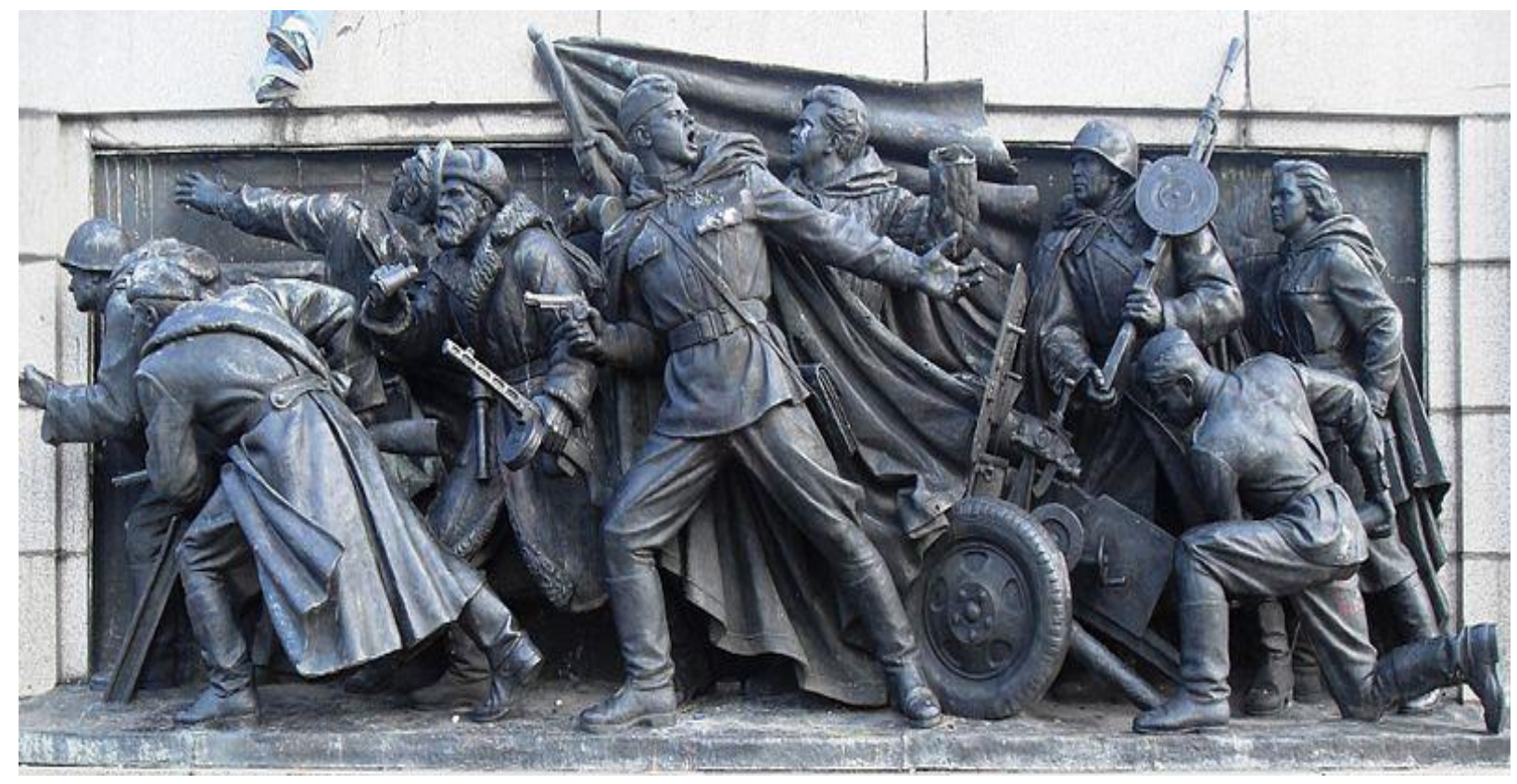

“Паметник на Съветската армия в София.” Уикипедия 21 Aug. 2014. Wikipedia. Web. 21 Aug. 2014.

http://bg.wikipedia.org/w/index.php?title=Паметник на Сьветската армия в Coфия\&oldid=6257561 


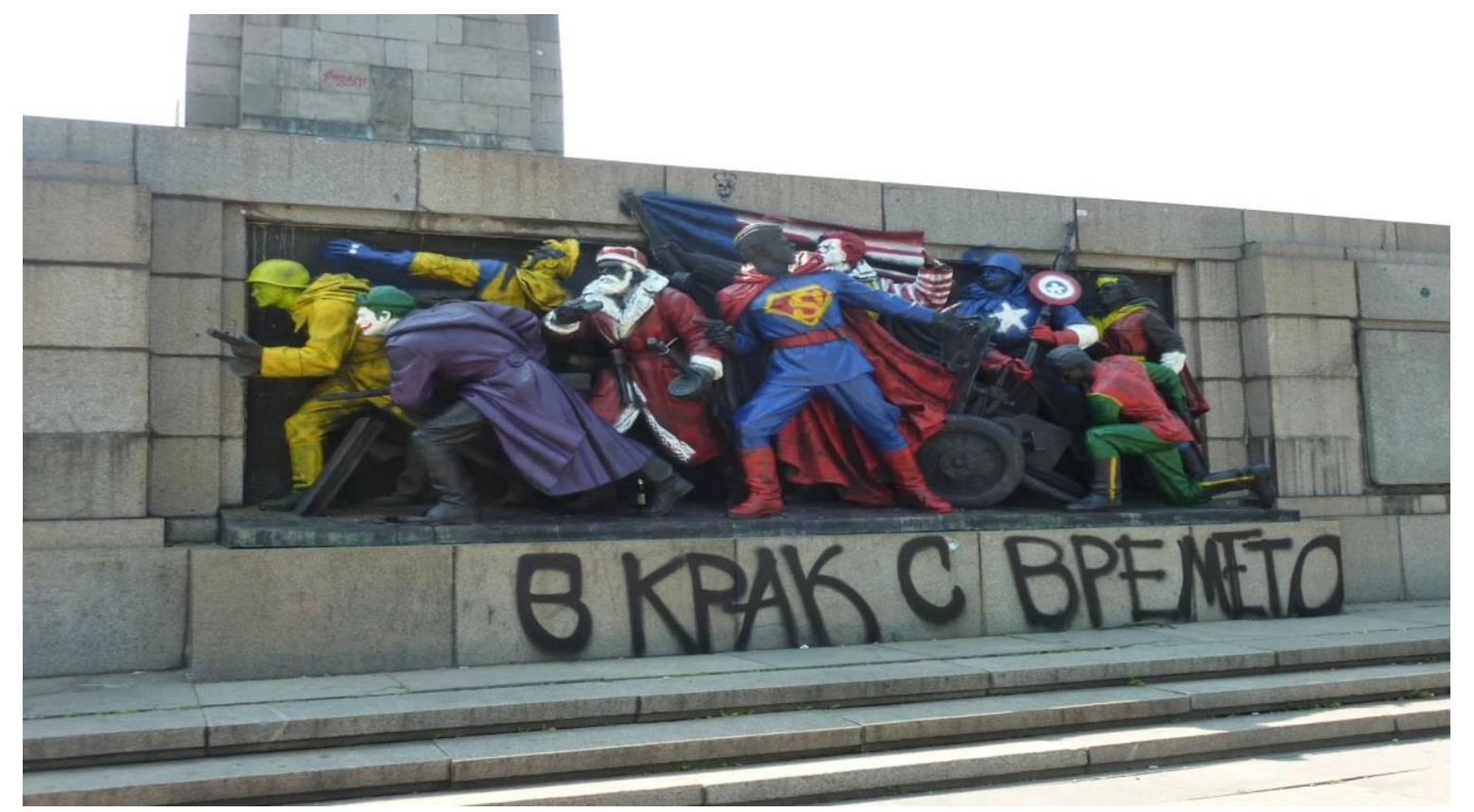

\section{Images are taken from Wikipedia}

"Monument to the Soviet Army, Sofia." Wikipedia, the free encyclopedia 17 Aug. 2014. Wikipedia. Web. 21 Aug. 2014. http://en.wikipedia.org/w/index.php?title=Monument to the Soviet Army, Sofia\&oldid=621600135

During the Cold War two equally opposing ideologies competed in a bipolar world. But after the fall of the Berlin Wall we face in the ideological formation of thought in culture, what Mikhail Bakhtin defines as monoglossia (the language of power, for Bakhtin that of state and church, that silences other languages) (Bakhtin). In the Western world the U.S. remains the sole arbiter of the master-signifier of democracy (Boyer and Yurchak). Yet, the winner position of the U.S. can no longer conceal the discrepancy between the ideological text and the lived experience under neoliberal regimes.

The provocation in Sofia in the summer of 2011 challenges the monoglossia of power with a carnivalesque inversion of meaning. It opens up many communicative discourses and creates heteroglossia (the opening up of dialogic voices). And here we have to go to Slavoj Žižek and his differentiation between the significance of argumentative persuasion in late capitalism and late socialism. If cynicism prevails in late capitalist culture where "words do not count" and everyone knows that the emperor is naked but acts as if he is not, late socialism is characterized with "almost paranoiac belief in the power of the Word" Thus, "belief in the power of the Word was the system's Achilles heel - it was possible to undermine the regime by civil society movements that operated at the level of the Word" (Žižek 19). The hysterical reaction of power towards the graffiti work shows the legacy of this belief in the Word and reveals that the cynicism of late capitalism, where "words do not count" cannot be established in peripheral regions, where mostly gangster elites reap its benefits.

In a Bakhtinian fashion the changing of clothes symbolizes changing of status, the graffiti seems to signify refusal to accept the transition to capitalism and democracy as master-signifier and the discourse that think-tanks and NGOs invented to justify its outcomes of neoliberal policies 
(Anguelova-Lavergne). Power changes its ideological clothes but remains oppressive. The political oppression of the many through enforced collectivism is substituted by the economic oppression of the few through consumerist hyper individualism. We can see that behind the consumer mascots and comic superheroes lurks the threatening face of U.S. imperialism. Now, the Monument of the Soviet Army translates symbolically into the unfinished commodity of the neoliberal project in the periphery. In the periphery the spectacle of pleasure cannot be realized; there are too many empty stomachs with too many memories of the scarce but affordable consumerism of late Socialism.

Many years ago, while a student at Sofia University I used to look at the MSA with anger and contempt. After less than a decade since the significant November events of 1989, it represented the dominance of a foreign power. It took the intervention of graffiti artists to make me realize that this space of power can become space for practicing liberty. I would like to conclude with Žižek's insightful discussion of the need to de-fetishize power and the example he uses taken from Lacan about the king who believes himself to be a king; the king is only a king in relations to his subjects; it is the social relations of power that form the perception of someone as a king. It is because of the subjects' acceptance that the king becomes a king. It would be interesting to engage in a playful exercise and relate it to the slogan of corporate capitalism - the customer is always king. Is not this precisely the problem of late capitalism - the fact that the customer or consumer has become a king neglecting his duties and responsibilities as a citizen and permitting in the process the abuse of financial, economic and political power? The MSA intervention, in an almost childishly naïve way, serves to remind us that the emperor continues to be naked. The Monument of the Soviet Army constitutes a symbolic space that signifies how the competing narratives and discourses about the Bulgarian historical experience can produce different meanings depending on the ideological lenses through which the past is considered. This is an open process that characterizes the political struggles over meaning-making in the cultural realm in Bulgaria today. 
TranscUlturAl, vol. 6.1 (2012), 56-66.

http://ejournals.library.ualberta.ca/index.php/TC

\section{REFERENCES}

Anguelova-Lavergne, Dostena. Ekspertite Na Prekhoda: Bulgarskite Think-Tanks I Globalnite Mrezhi Za Vliianie [Experts of the Transition: Bulgarian Think Tanks and the Global Influence Networks]. Sofiiä: Istok Zapad, 2010.

Bakhtin, M. M. Rabelais and His World. Bloomington: Indiana University Press, 1984.

Bakhtin, M. M. "Discourse of the Novel." The Dialogic Imagination: Four Essays. University of Texas Press, 1982.

Benjamin, Walter. "The Work of Art in the Age of Mechanical Reproduction." Illuminations. Houghton Mifflin Harcourt, 1968. 217-253.

Boyer, Dominic, and Alexei Yurchak. "AMERICAN STIOB: Or, What Late-Socialist Aesthetics of Parody Reveal about Contemporary Political Culture in the West." Cultural Anthropology 25.2 (2010): 179-221. Wiley Online Library. Web. 30 Sept. 2012.

Certeau, Michel de. "'Making Do': Uses and Tactics." The Practice of Everyday Life. University of California Press, 2011. 29-43.

Daskalov, Rumen. Debating the Past: Modern Bulgarian History: From Stambolov to Zhivkov. Central European University Press, 2011.

Daskalov, Rumen. The Making of a Nation in the Balkans: Historiography of the Bulgarian Revival. Central European University Press, 2004.

Daskalov, Roumen. "Transformations of the East European Intelligentsia: Reflections on the Bulgarian Case.” East European Politics \& Societies 10.1 (1995): 46-84. eep.sagepub.com.proxy.lib.sfu.ca. Web. 1 Oct. 2012.

“Destructive Creation: Изобразихме Българската Политика, Която Се Нагажда Винаги Спрямо Посоката На Вятьра.” wmw.dnevnik.bg. online newspaper. N.p., n.d. Web. 28 Sept. 2012.

“dirty.ru." social media. N.p., n.d. Web. 30 Sept. 2012.

Foucault, Michel. The Foucault Reader. New York: Pantheon Books, 1984.

Hobsbawm, Eric. "Introduction: Inventing Traditions." The Invention of Tradition. Ed. Eric Hobsbawm and Terence Ranger. Cambridge University Press, 1992.

Hobsbawm, Eric, and Terence Ranger. "Mass Producing Traditions: Europe 1870 - 1914." The Invention of Tradition. Cambridge University Press, 1992. 
Kiossev, Alexander. "The Dark Intimacy: Maps, Identities, Acts of Identification." Balkan as Metaphor: Between Globalization and Fragmentation. Ed. Dušan I. Bjelic and Obrad Savic. MIT Press, 2005.

"Monument to the Soviet Army, Sofia." Wikipedia, the free encyclopedia 17 Aug. 2014. Wikipedia. Web. 21 Aug. 2014.

“Moving with the Times.” CNN iReport. N.p., n.d. Web. 29 Sept. 2012.

Nikolaev, Nikolai, and Zhivka Popatanasova. “Аве Мнения За Паметника На Съветската Армия.” Новини от Перник за хората и сьбитията, актуално и обективно. online newspaper. N.p., n.d. Web. 29 Sept. 2012.

"Red Army Soldiers Gone Superhero: Graffiti Artist Transforms Soviet Monument in Sofia." Zikata's Blog. Blog. N.p., n.d. Web. 29 Sept. 2012.

Sharlanov, Diniū. Горяните. Kои са те?: Из строго секретните архиви на дирекиия на двржавна сигрност. Пространство \& Форма, 1999.

Sygkelos, Yannis. "The National Discourse of the Bulgarian Communist Party on National Anniversaries and Commemorations (1944-1948)." Nationalities Papers 37.4 (2009): 425-442. Taylor and Francis+NEJM. Web. 6 Oct. 2012.

Todorova, Maria. "Course and Discourses of Bulgarian Nationalism." Eastern European Nationalism in the Twentieth Century. Ed. Peter F. Sugar. Lanham, Md: American University Press, 1995. Print.

"Vesti.bg - Затвор Грози Неизвестния Художник На Паметника На Съветската Армия." N.p., n.d. Web. 28 Sept. 2012.

"Who Is in Step with the Times?” Edno magazine. magazine. N.p., n.d. Web. 30 Sept. 2012.

Zizek, Slavoj. “The Spectre of Ideology.” Mapping Ideology. Ed. Slavoj Žižek. London; New York: Verso, 1994.

“Американизираха Паметника На Съветската Армия | Webcafe.bg.” Webcafe. online media. N.p., n.d. Web. 29 Sept. 2012.

“В Крак С Времето | Трънки И Блогинки.” Trunki i Bloginki. blog. N.p., n.d. Web. 29 Sept. 2012. “В Русия - Вой 3а ‘Осквернения’ Паметник На Съветската Армия.” Frognews. online news media. N.p., n.d. Web. 29 Sept. 2012.

“Вежди Рашидов: Боядисването На Паметника Е Вандализъм.” www.dnevnik.bg. online 
TranscUlturAl, vol. 6.1 (2012), 56-66.

http://ejournals.library.ualberta.ca/index.php/TC

newspaper. N.p., n.d. Web. 29 Sept. 2012.

“Въпроси В Крак С Времето.” Блогът на нервната акула. Blog. N.p., n.d. Web. 29 Sept. 2012.

“Аали Си Герой Или Антигерой Не Е Толкова Важно, В Крайна Сметка Всички Сме Равни” - Mediapool.bg." Mediapool.bg. N.p., n.d. Web. 28 Sept. 2012.

“Аоцент А-Р Арх. Аобрина Желева-Мартинс Виана» ПАМЕТНИКЪТ НА СЪВЕТСКАТА АРМИЯ 1954 - 2011.” Web. 21 Aug. 2014.

“ГАасът На Русия’: ‘България: УАично Изкуство ИАи Вандализъм?’ - СВЯТ - Новини Телевизия Европа.” TV Evropa. TV network website. N.p., n.d. Web. 28 Sept. 2012. 